Bulgarian Academy of Sciences. Space Research and Technology Institute.

Aerospace Research in Bulgaria. 32, 2020, Sofia

DOI: https://doi.org/10.3897/arb.v32.e04

\title{
SPATIAL MODELING OF ARCHAEOLOGICAL LANDSCAPES WITH UAV AND DIGITAL PHOTOGRAMMETRY
}

\author{
Jordan Tzvetkov \\ Space Research and Technology Institute - Bulgarian Academy of Sciences \\ e-mail: jordan.tzvetkov@gmail.com
}

Key worlds: Archaeology, Landscape, UAV, Modeling, Digital Photogrammetry

\begin{abstract}
The aim of this article is to present the results of spatial (2D and 3D) modeling of selected archaeological landscapes (Kaliakra, Chirakman, Provadia-Solnitsata, Debelt-Deultum, Halka Bunar) which was part of the project "Archaeological map of Bulgaria" during 2017 - 2018. To create these spatial models we used aerial (UAV) photography and digital photogrammetry. The main goal of this research was to prove the potential of UAV deployment of creating low-cost spatial models for archaeological tasks.
\end{abstract}

\section{Introduction}

Since archaeological excavation is a destructive process it's crucial scientific task to accurately document the entire process. One of the most important techniques for documenting is photographing the archaeological sites [1]. But along with ground photography aerial perspective is also very valuable so aerial photography and aerial reconnaissance started to be part of documenting the archaeological landscapes. This lead to develop new scientific branches like aerial archaeology and to distinguish new landscape features (crop marks, soil marks, shadow marks etc.) used to find new archaeological sites [2].

Modern technological development enriches this field with new methods for archaeological research like: satellite images; unmanned aerial vehicles (UAVs) also known as unmanned aircraft systems (UASs) or just drones; airborne laser scanning (LiDAR); digital photogrammetry; geographical information systems (GIS) [3-7]. Some of them are already used in Bulgaria for archaeological purposes [8-10]. Great opportunities to apply these methods are projects for national archaeological mapping existing in many European counties from Romania to Scotland $[11,12]$. Bulgaria also has its archaeological map developed by National Archaeological Institute with Museum - NAIM (Bulgarian Academy 
of Sciences - BAS) [13]. An important stage of its development was conducted by the project of BAS "Archaeological map of Bulgaria" during 2017 - 2018 [14].

The aim of this study (which also was part of the project "Archaeological map of Bulgaria") is to accomplish aerial photography and to create spatial (2D and 3D) models of five archaeological sites and their landscapes (specified by NAIM) with ground sampling distance (GSD) at $7.00 \mathrm{~cm} /$ pixel or higher. These archaeological landscapes are: (1) Kaliakra - antiquity and medieval site (Kavarna Municipality, Dobrich Province); (2) Chirakman - antiquity and medieval site (Kavarna Municipality, Dobrich Province); (3) Provadia-Solnitsata - prehistoric (chalcolithic) site (Provadia Municipality, Varna Province); (4) Debelt-Deultum antiquity and medieval site (Sredets Municipality, Burgas Province); (5) Halka Bunar - antiquity site (Bratia Daskalovi Municipality, Stara Zagora Province).

\section{Data and Methods}

To conduct this research we use a combination of UAV photography and digital photogrammetry also known as UAV photogrammetry [15].

For aerial image acquisition we used UAV DJI Phantom 3 Advanced with RGB camera FC300S (sensor 1/2.3", width $6.16 \mathrm{~mm}$, height $4.62 \mathrm{~mm}$, diagonal $7.7 \mathrm{~mm}, 4000 \times 3000$ pixels, 12 Megapixels) and software DJI Go and DJI Ground Station Pro (for flight mission planning).

Table 1. General specifications of the input data

\begin{tabular}{|l|c|c|c|c|}
\hline Archaeological Site & $\begin{array}{c}\text { Total Number } \\
\text { of Images }\end{array}$ & $\begin{array}{c}\text { Number of } \\
\text { Images for } \\
\text { 2D/3D } \\
\text { Models }\end{array}$ & $\begin{array}{c}\text { GSD } \\
\text { (cm/pixel) }\end{array}$ & $\begin{array}{c}\text { GCPs } \\
\text { for } \\
\text { Orthorectification }\end{array}$ \\
\hline Kaliakra & 587 & 435 & 5 & No \\
\hline Chirakman & 514 & 188 & 7 & No \\
\hline Provadia-Solnitsata & 512 & 427 & $6 ; 2 ; 3$ & Yes \\
\hline Debelt-Deultum & 3624 & 3069 & 6 & Yes \\
\hline Halka Bunar & 1237 & 968 & 6 & No \\
\hline
\end{tabular}

For spatial modeling purpose we used $75 \%$ frontal overlap and $60 \%$ side overlap and regular grid for taking images. For the initial image dataset we provide quality check and removed blur images if they exist. Then we selected the image datasets used for spatial modeling excluding non-nadir images (Table 1). For some archaeological sites NAIM provided coordinates of existing Ground Control Points (GCPs) for high accuracy georeferencing. Some of them used an outdated Bulgarian coordinate system 1970 (Krasovsky 1942 ellipsoid) which we transformed to UTM zone 35N, datum WGS 1984 with BGSTrans v.4.2 coordinate transformation software (freely distributed by Bulgarian Geodesy, Cartography and 
Cadastre Agency). Before image acquisition these GCPs were marked on the field. If no GCPs exist for image georeferencing we used the DJI geotagged photos with onboard GNSS/GPS.

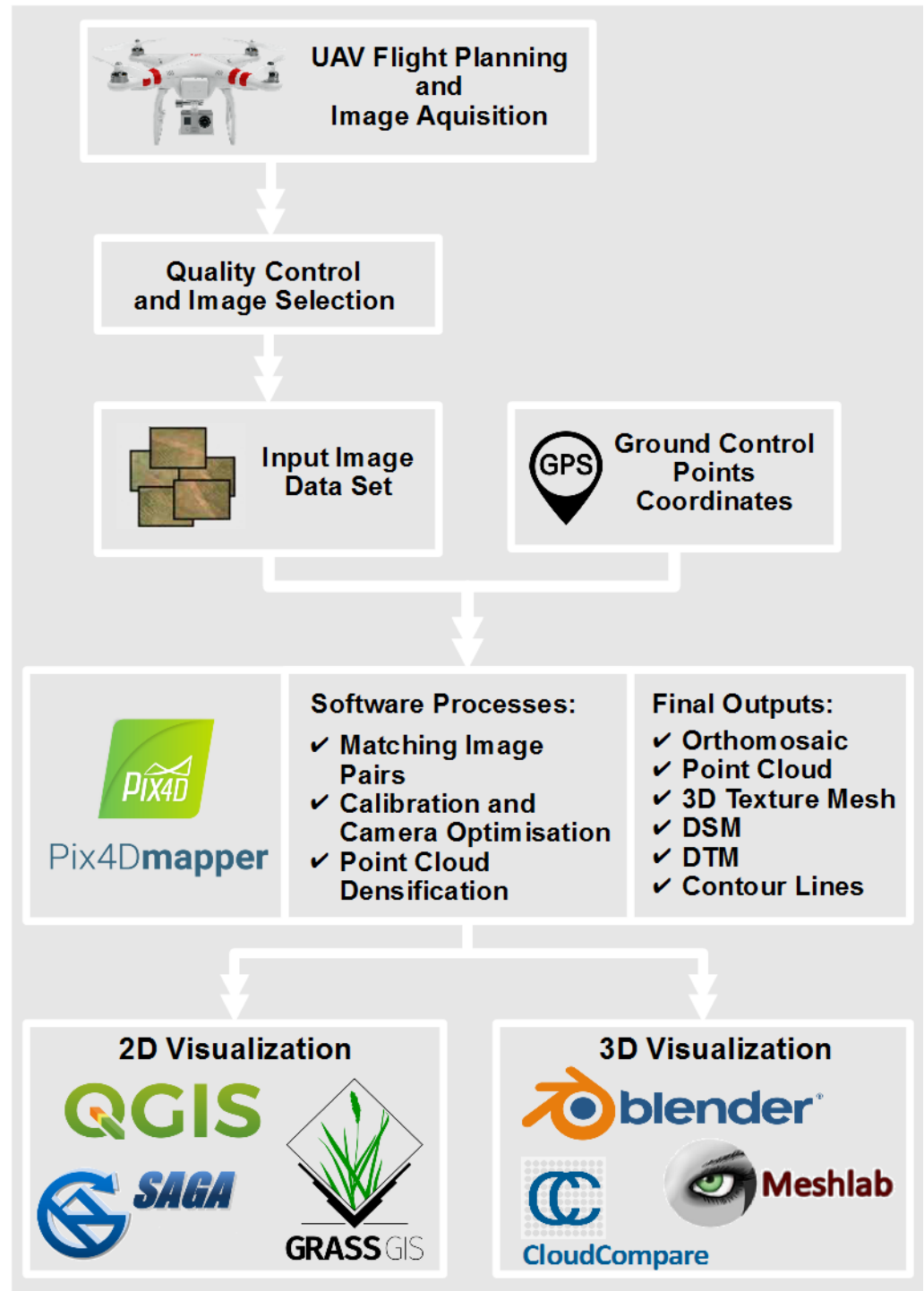

Fig. 1. Workflow of the data processing

The next step of the workflow was data processing. Since our goal was to create 2D and 3D spatial models we used digital photogrammetry and Structure 
from Motion (SfM) algorithms [16-18]. For this task from several software opportunities we choose Pix4Dmapper software, because of its high quality in creation dense point clouds [19] and many other advantages including: designed for geospatial application; cloud service (avoiding high hardware system requirements for fast data processing) etc.

The entire workflow of the data processing is shown on Fig. 1. For all input data we apply same software settings to create outputs, including: point cloud, 3D texture mesh, orthophoto mosaic, digital surface model (DSM with resolution $1 \times$ GSD), digital terrain model (DTM with resolution $5 \times$ GSD) and contour lines.

\section{Results}

The total area we covered is approximate $10.75 \mathrm{~km}^{2}$ (1075 ha). For visualization of the final output models we used several free and open source software packages like QGIS for 2D and MeshLab for 3D visualization (Fig. 1).

The Provadia-Solnitsata archaeological landscape covers $0.78 \mathrm{~km}^{2}$ (78 ha). The whole archaeological landscape (Provadia-Solnitsata 1) has $6 \mathrm{~cm} /$ pixel resolution and two different parts of it which are of special interest have greater resolution $-2 \mathrm{~cm}$ (Provadia-Solnitsata 2) and $3 \mathrm{~cm}$ (Provadia-Solnitsata 3) respectively. Georeferencing accuracy of the spatial models with GCPs by Pix4D reports is shown on Table 2. A visualization of the Provadia-Solnitsata mould (Provadia-Solnitsata 2) is shown on Fig. 2. Debelt-Deultum archaeological landscape is largest and covers $6.35 \mathrm{~km}^{2}$ (635 ha). This landscape we divided to five separate parts with $6 \mathrm{~cm}$ resolution. Two of them have GCPs (Table 2). A visualization of one of them (Debelt-Deultum 5) is shown on Fig. 3. The Chirakman archaeological landscape covers $0.47 \mathrm{~km}^{2}$ (47 ha). It has $7 \mathrm{~cm}$ spatial resolution and visualization is shown on Fig. 4. The Kaliakra archaeological landscape covers $0.82 \mathrm{~km}^{2}$ ( $82 \mathrm{ha}$ ). It has $5 \mathrm{~cm}$ spatial resolution and visualization is shown on Fig. 5. The Halka Bunar archaeological landscape covers $2.33 \mathrm{~km}^{2}$ (233 ha). It has $6 \mathrm{~cm}$ spatial resolution and visualization is shown on Fig. 6.

Table 2. Georeferencing accuracy of the spatial models with GCPs

\begin{tabular}{|l|c|c|c|c|c|}
\hline $\begin{array}{c}\text { Archaeological } \\
\text { Landscape Models }\end{array}$ & $\begin{array}{c}\text { Number } \\
\text { of } \\
\text { GCPs }\end{array}$ & $\begin{array}{c}\text { RMS } \\
\text { Error X } \\
(\mathrm{m})\end{array}$ & $\begin{array}{c}\text { RMS Error } \\
\text { Y (m) }\end{array}$ & $\begin{array}{c}\text { RMS } \\
\text { Error Z } \\
(\mathrm{m})\end{array}$ & $\begin{array}{c}\text { RMS } \\
\text { Error Mean } \\
(\mathrm{m})\end{array}$ \\
\hline Provadia-Solnitsata 1 & 13 & 0.070 & 0.132 & 0.445 & 0.203 \\
\hline Provadia-Solnitsata 2 & 4 & 0.007 & 0.062 & 0.070 & 0.045 \\
\hline Debelt-Deultum 3 & 3 & 0.323 & 0.453 & 8.764 & 0.484 \\
\hline Debelt-Deultum 5 & 3 & 0.069 & 0.039 & 0.123 & 0.068 \\
\hline
\end{tabular}




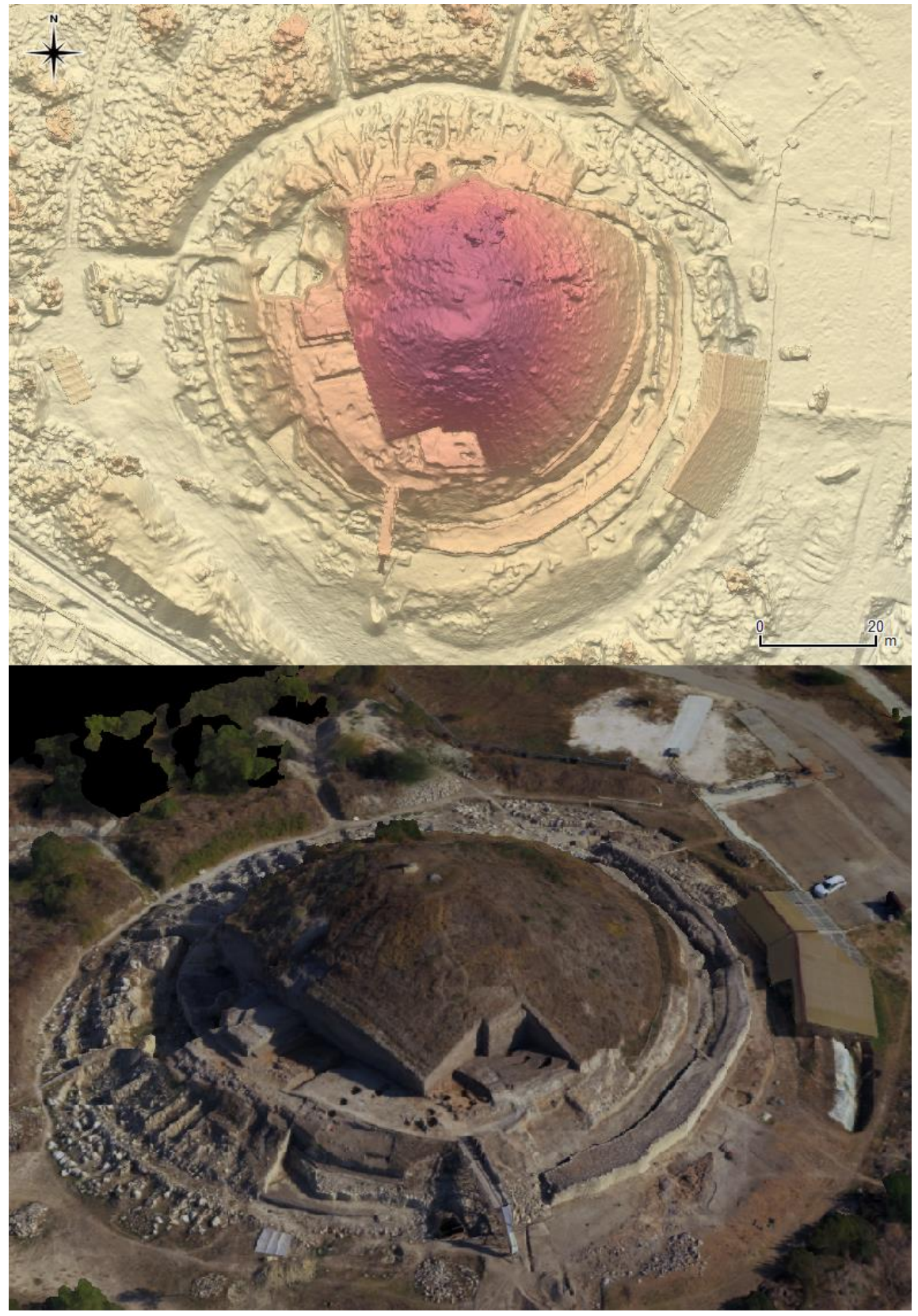

Fig. 2. Provadia-Solnitsata archaeological site. Top: DSM visualization - multidirectional hillshade with color gradient (QGIS software). Bottom: $3 D$ texture mesh visualization (MeshLab software) 


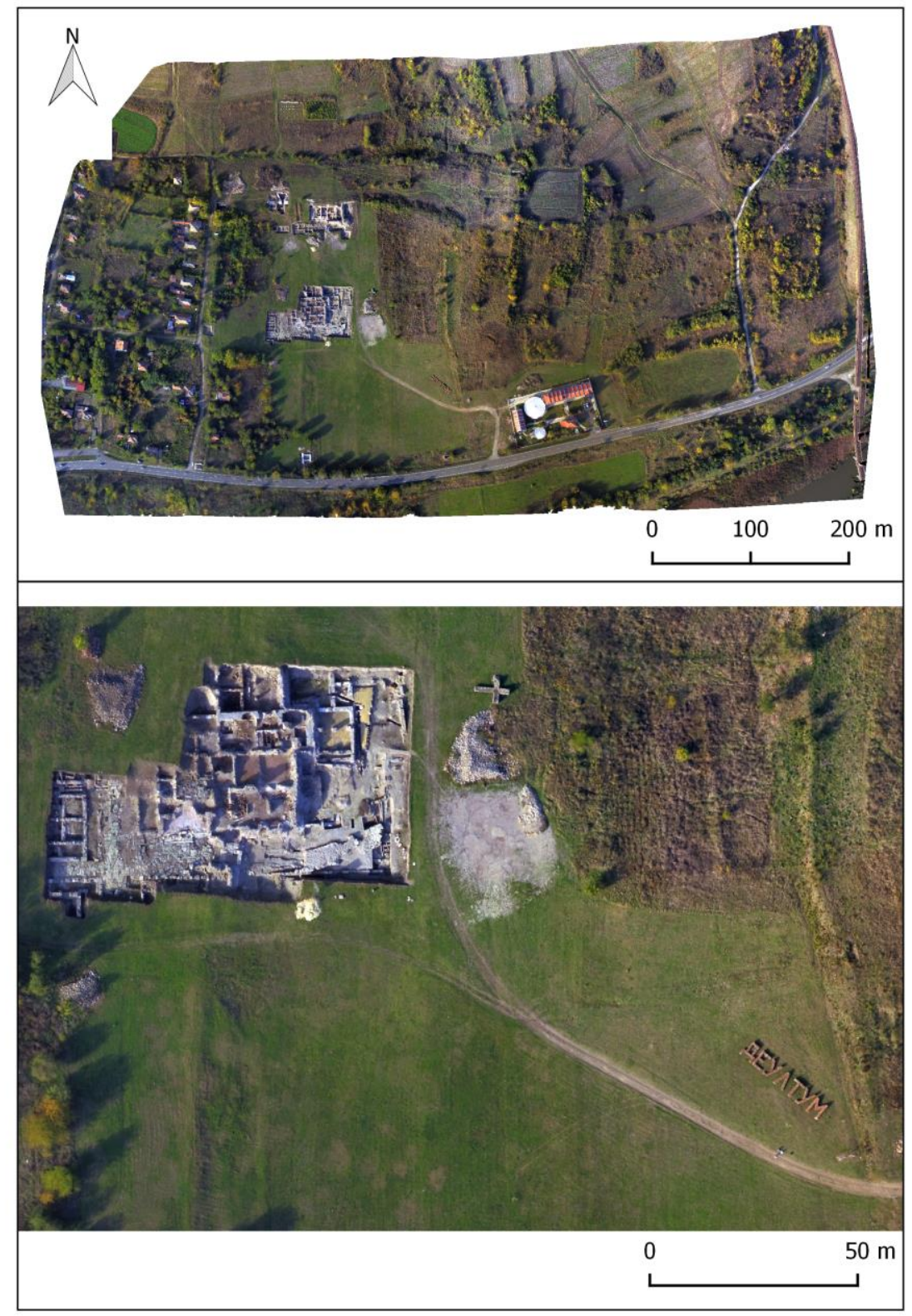

Fig. 3. Debelt-Deultum archaeological landscape. Orthophoto visualization-fragment for the east part at two different scales (QGIS software) 


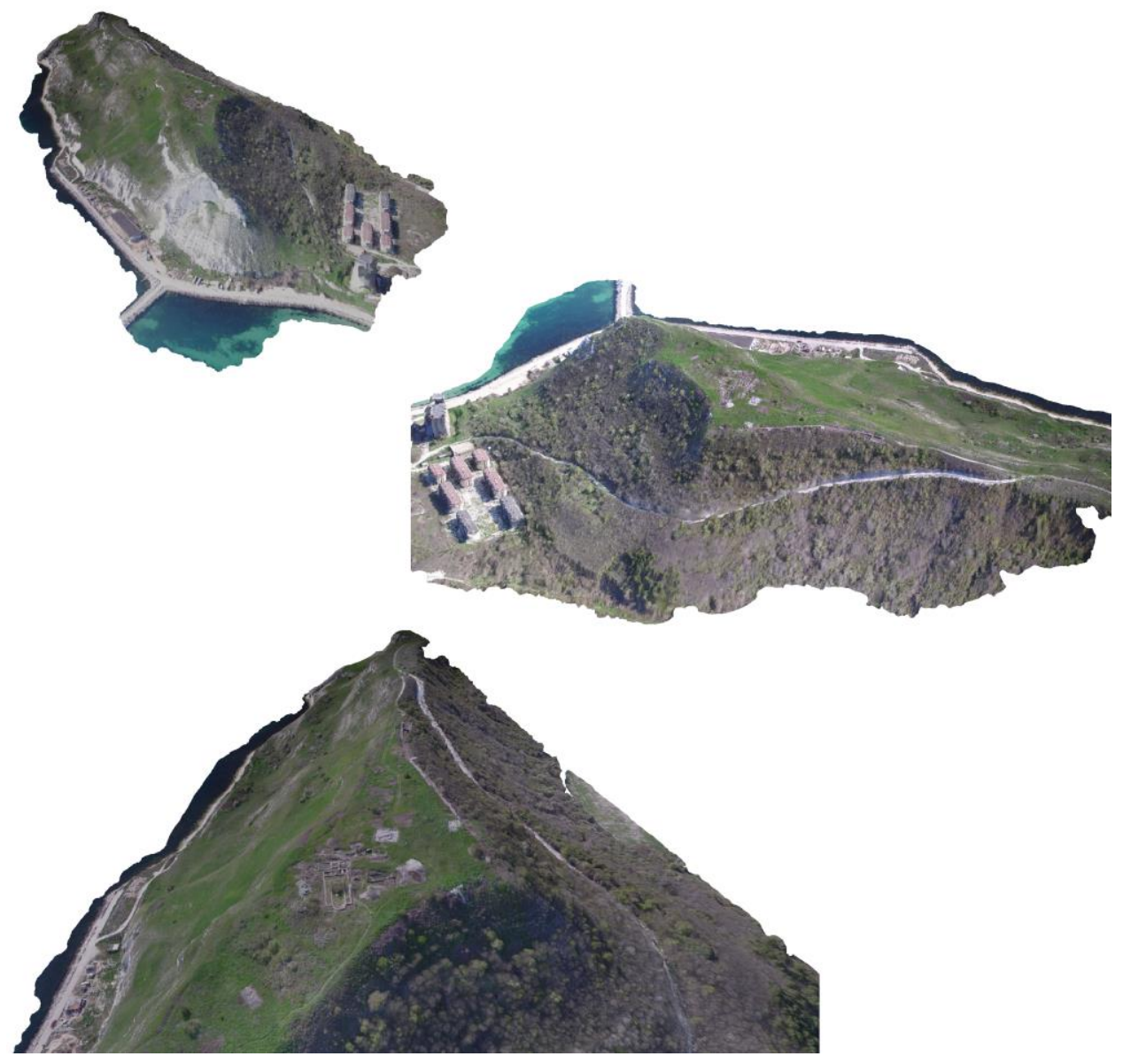

Fig. 4. Chirakman archaeological landscape. 3D texture mesh visualization (MeshLab and CloudCompare software) 

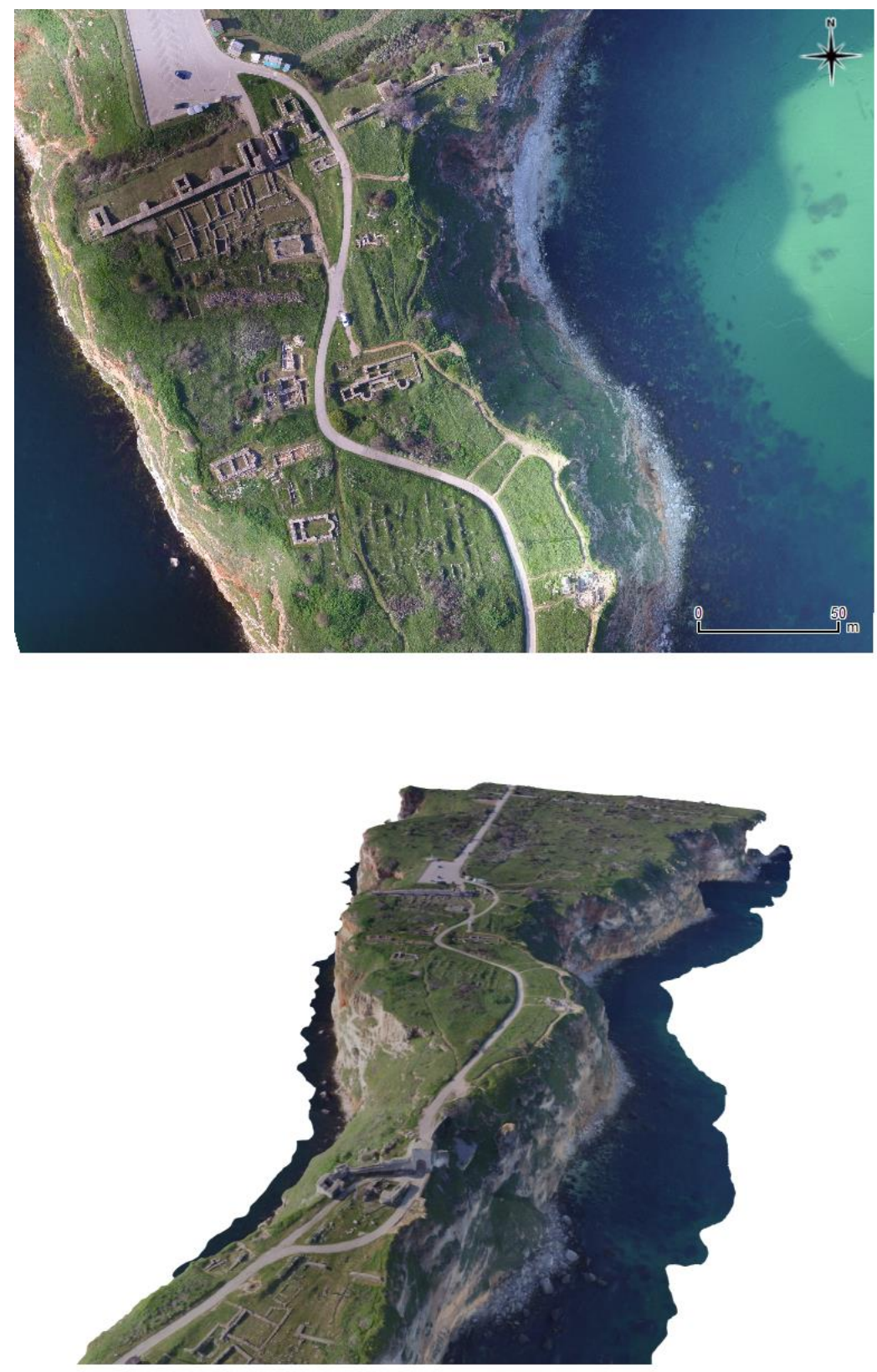

Fig. 5. Kaliakra archaeological landscape. Top: Orthophoto visualization - fragment (QGIS software). Bottom: 3D texture mesh visualization (MeshLab software) 


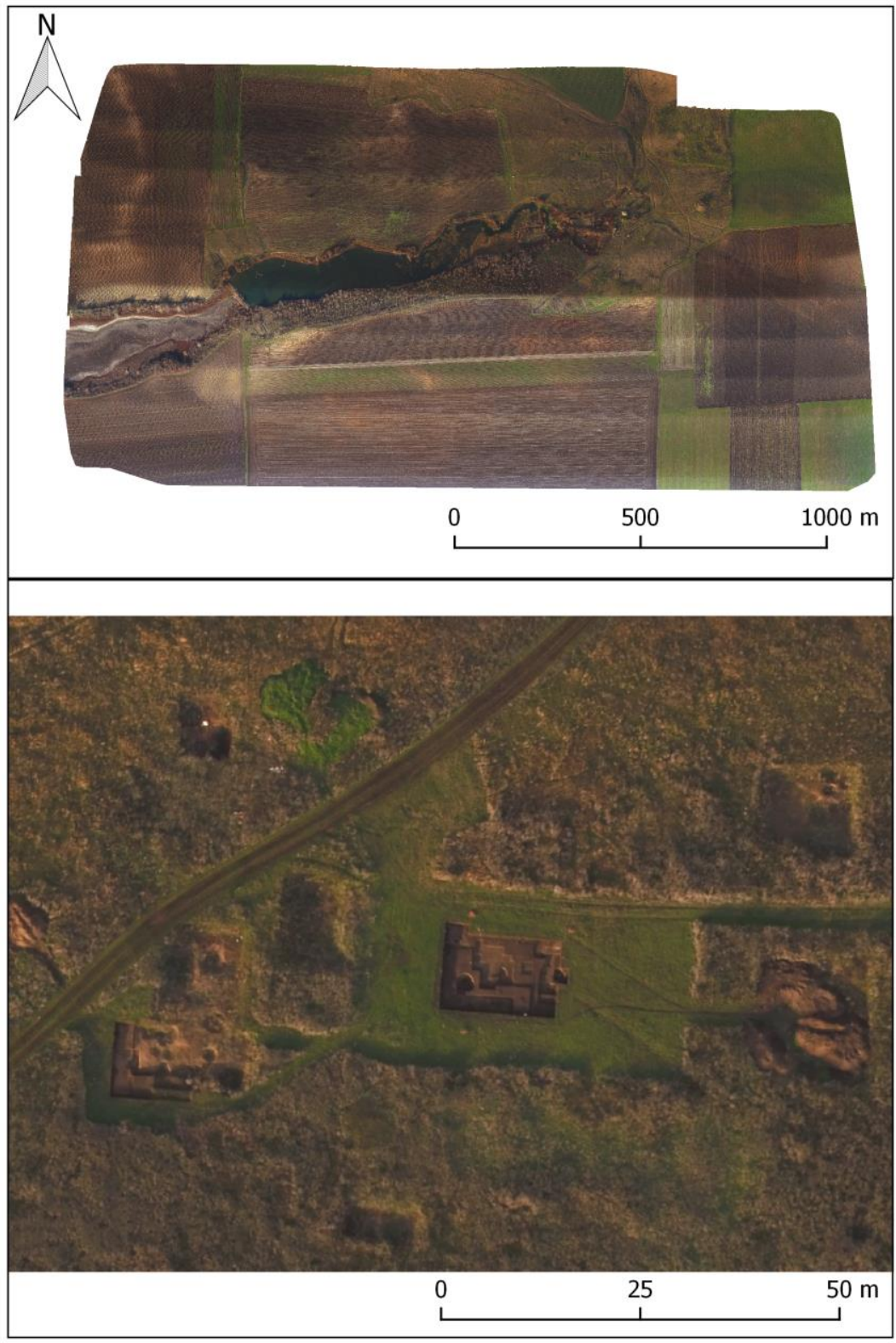

Fig. 6. Halka Bunar archaeological landscape. Orthophoto visualization at two different scales (QGIS software) 


\section{Conclusion}

The presented above results are part of national level program of archaeological survey. The main goal of UAV deployment was to prove the potential of creating low-cost aerial photography and spatial modeling for archaeological tasks.

Some facilitation of field image acquisition was the lack of specific drone legal regulations in Bulgaria but this may change in near future.

The advantages of UAV deployment include low-cost high resolution photography; easy photography and aerial reconnaissance for terrains with difficult access; simple and fast 2D and 3D spatial modeling; many opportunities for visualization with different purposes: for future field investigations; for archaeology and cultural heritage popularization and preservation etc.

Future UAVs deployment in archaeology should include emphasis upon multispectral aerial reconnaissance for new archaeological site detection. Also an airborne laser scanning for the whole territory of Bulgaria will be of great concern.

\section{Acknowlegments}

I would like to express my gratitude to Bulgarian Academy of Sciences for funding this research; to National Archaeological Institute with Museum for creating the Project "Archaeological map of Bulgaria"; to Georgi Nekhrizov and Nadezhda Kecheva from NAIM-BAS; to Dimo Zafirov from Space Research and Technology Institute, Bulgarian Academy of Sciences (SRTI-BAS) for UAV image capturing on the field.

\section{References}

1. Dorrell, P. Photography in Archaeology and Conservation ( $2^{\text {nd }}$ edn). Cambridge, Cambridge Univ. Press, 1994.

2. Musson, C., R. Palmer, S. Campana. Flights into the Past: Aerial Photography, Photo Interpretation and Mapping for Archaeology. Occasional Publ. No. 4 of the Aerial Archaeology Research Group, 2013. http://archiv.ub.uni-heidelberg.de/ propylaeumdok/volltexte/2013/2009

3. Parcak, S. Satellite Remote Sensing for Archaeology. London, N. Y., Routledge, 2009.

4. Verhoeven, G. Beyond Conventional Boundaries: New Technologies, Methodologies, and Procedures for the Benefit of Aerial Archaeological Data Acquisition and Analysis. Doctoral Thesis, Ghent University. Zelzate (Belgium), Nautilus Academic Books, 2009. http://hdl.handle.net/1854/LU-631969

5. Lasaponara, R., N. Masini (eds). Satellite Remote Sensing: A New Tool for Archaeology. Springer Science \& Business Media, 2012.

6. Corsi, C., B. Slapšak, F. Vermeulen (eds). Good Practice in Archaeological Diagnostics: Non-invasive Survey of Complex Archaeological Sites. Cham, Springer, 2013. 
7. Opitz, R., D. Cowley (eds). Interpreting Archaeological Topography: Lasers, 3D Data, Visualisation and Observation. Oxford UK, Oxbow Books, 2013.

8. Stamenov, S. Remote sensing and GIS in Bulgarian archaeology. In: $30^{\text {th }}$ EARSeL Symposium, Remote Sensing for Science, Education, and Natural and Cultural Heritage. UNESCO, Paris, 31 May - 3 June, 2010, 677-82.

9. Prahov, N., H. Angelova, A. Kotsev, et al. Predictive modeling in archaeology: world practice and Bulgarian perspectives. Bulgarian e-Journal of Archaeology, 2011, 1, 1, 71-121 (in Bulgarian). http://be-ja.org/index.php/Be-JA/article/view/48

10. Kunze, R., J. Abele, P. Leshtakov, et al. Archaeometallurgical prospections in the highlands of Medni Rid, southeastern Bulgaria. Preliminary report on fieldwork 2013-2015 with a focus upon remote sensing methods by means of LiDAR. Journal of Archaeological Science: Reports, 2018, 19, 596-617. DOI: 10.1016/j.jasrep.2018.03.021

11. Posluschny, A. (ed.). Sensing the Past: Contributions from the ArcLand Conference on Remote Sensing for Archaeology. Bonn, ArcLand, 2015. DOI:10.11588/ propylaeumdok.00002513

12. Banaszek, Ł., D. Cowley, M. Middleton. Towards national archaeological mapping. Assessing source data and methodology - A case study from Scotland. Geosciences, 2018, 8, 8, 272. DOI:10.3390/geosciences8080272

13. Kecheva, N. Archaeological Map of Bulgaria - Non-Destructive Methods for Field Archaeological Surveying and Applications of GIS. Ph.D. Thesis. Sofia, National Archaeological Institute with Museum, Bulgarian Academy of Sciences, 2018 (in Bulgarian).

14. Nekhrizov, G. Project "Archaeological map of Bulgaria". Bulgarian e-Journal of Archaeology, 2018, 8, 2, 197-212 (in Bulgarian). http://www.be-ja.org/index.php/ Be-JA/article/view/177/160

15. Eisenbeiß H. UAV Photogrammetry. Ph.D. Dissertation, ETH Zurich, ETH No 18515, 2009. URL: http://www.igp-data.ethz.ch/berichte/Blaue_Berichte_PDF/105.pdf

16. Remondino, F., S. Campana (eds). 3D Recording and Modelling in Archaeological and Cultural Heritage. Theory and Best Practices. BAR International Series 2598, 2014.

17. Historic England. Photogrammetric Applications for Cultural Heritage. Guidance for Good Practice. Swindon, Historic England, 2017. https://historicengland.org.uk/ images-books/publications/photogrammetric-applications-for-cultural-heritage/

18. Carrivick, J., M. Smith, D. Quincey. Structure from Motion in Geosciences. Chichester, John Wiley \& Sons, 2016.

19. Federman, A., M. Santana Quintero, S. Kretz, et al. UAV photogrammetric workflows: A best practice guideline. The International Archives of the Photogrammetry, Remote Sensing and Spatial Information Sciences, Vol. XLII-2/W5. 26th International CIPA Symposium - Digital Workflows for Heritage Conservation, 28 August - 01 September, 2017, Ottawa, Canada. https://www.int-arch-photogrammremote-sens-spatial-inf-sci.net/XLII-2-W5/237/2017/isprs-archives-XLII-2-W5237-2017.pdf 


\title{
ПРОСТРАНСТВЕНО МОДЕЛИРАНЕ НА АРХЕОЛОГИЧЕСКИ ЛАНДШАФТИ ЧРЕЗ БЛА И ЦИФРОВА ФОТОГРАМЕТРИЯ
}

\author{
Й. Цветков
}

\section{Резюме}

В статията са представени резултатите от въздушното заснемане и пространственото моделиране на избрани археологически ландшафти част от проекта на НАИМ-БАН „Археологическа карта на България” (2017-2018г.). Въздушното фотографско заснемане е осъществено чрез БЛА (безпилотен летателен апарат) тип DJI Phantom 3, а пространственото моделиране е извършено чрез софтуер за цифрова фотограметрия Pix4Dmapper. Заснетите археологически ландшафти са „Калиакра“, „Чиракман“, „ПровадияСолницата“, „Дебелт-Деултум“ и „Халка Бунар“ с обща площ 10.75 km². За всеки заснет обект е съставена серия от 2D и 3D модели: облак точки, 3D текстура, ортофото мозайка, цифров модел на повърхността (DSM), цифров модел на терена (DTM) и контурни линии. Резултатите от проучването доказват приложимостта и полезността на БЛА и цифровата фотограметрия като сравнително евтин и бърз метод за документиране и моделиране на археологически ландшафти за целите на археологическите разкопки, теренни проучвания в труднодотъпни местности и за целите на консервацията и популяризирането на културното наследство. 